\title{
Podocytopathy and Nephrotic Syndrome in Mice with Podocyte-Specific Deletion of the Asah1 Gene
}

\section{Role of Ceramide Accumulation in Glomeruli}

Guangbi Li, ${ }^{*}$ Jason Kidd, ${ }^{\dagger}$ Cristin Kaspar, ${ }^{\dagger}$ Sara Dempsey, ${ }^{\star}$ Owais M. Bhat, ${ }^{*}$ Sarah Camus, ${ }^{*}$ Joseph K. Ritter, ${ }^{*}$ Todd W.B. Gehr, Erich Gulbins, ${ }^{\ddagger}$ and Pin-Lan Li*

From the Department of Pharmacology and Toxicology* and the Division of Nephrology, ${ }^{\dagger}$ School of Medicine, Virginia Commonwealth University, Richmond, Virginia; and the Department of Molecular Biology, ${ }^{\ddagger}$ University of Duisburg-Essen, Essen, Germany

\author{
Accepted for publication \\ February 20, 2020 \\ Address correspondence to Pin- \\ Lan Li, M.D., Ph.D., Depart- \\ ment of Pharmacology and \\ Toxicology, School of Medi- \\ cine, Virginia Commonwealth \\ University, 1220 E Broad St., \\ Richmond, VA 23298 \\ 0613. E-mail: pin-lan.li@ \\ vcuhealth.org.
}

\begin{abstract}
Lysosomal acid ceramidase (Ac) has been shown to be critical for ceramide hydrolysis and regulation of lysosome function and cellular homeostasis. In the present study, we generated a knockout mouse strain $\left(\right.$ Asah $1^{\mathrm{fl} / \mathrm{fl}} / \mathrm{Podo}^{\mathrm{Cre}}$ ) with a podocyte-specific deletion of the $\alpha$ subunit (main catalytic subunit) of Ac. Although no significant morphologic changes in glomeruli were observed in these mice under light microscope, severe proteinuria and albuminuria were found in these podocyte-specific knockout mice compared with control genotype littermates. Transmission electron microscopic analysis showed that podocytes of the knockout mice had distinctive foot process effacement and microvillus formation. These functional and morphologic changes indicate the development of nephrotic syndrome in mice bearing the Asah1 podocyte-specific gene deletion. Ceramide accumulation determined by liquid chromatography-tandem mass spectrometry was demonstrated in isolated glomeruli of Asah $1^{\mathrm{fl} / \mathrm{fl} /}$ Podo ${ }^{\text {Cre }}$ mice compared with their littermates. By crossbreeding Asah $1^{\mathrm{fl} / \mathrm{fl} /} / \mathrm{Podo}^{\mathrm{Cre}}$ mice with Smpd1 ${ }^{-/-}$ mice, we also produced a double knockout strain, Smpd1 ${ }^{-/} /$Asah $^{\mathrm{fl} / \mathrm{fl}} / \mathrm{Podo}^{\text {Cre }}$, that also lacks Smpd1, the acid sphingomyelinase that hydrolyzes sphingomyelin to ceramide. These mice exhibited significantly lower levels of glomerular ceramide with decreased podocyte injury compared with Asah $1^{\mathrm{fl} / \mathrm{fl} /}$ Podo ${ }^{\text {Cre }}$ mice. These results strongly suggest that lysosomal Ac in podocytes is essential for the maintenance of the structural and functional integrity of podocytes. (Am J Pathol 2020, 190: 1211-1223; https://doi.org/10.1016/j.ajpath.2020.02.008)
\end{abstract}

Podocytes are terminally differentiated epithelial cells covering the outer surface of the glomerular capillaries, which do not typically proliferate. Most glomerular diseases in which the podocyte is the target of injury are not associated with podocyte proliferation. ${ }^{1,2}$ Therefore, normal function of lysosomes as the major degradative compartments to renew cellular activity is essential for maintenance of podocyte structural and functional integrity. In this regard, genetic studies with gene knockout strategy showed that slit diaphragm proteins, nuclear proteins, actin cytoskeleton proteins, and mitochondrial proteins in podocytes are important in the regulation of podocyte function and glomerular permeability. ${ }^{3}$ However, it remains poorly understood whether lysosomal proteins for the control of autophagy and related cellular activities participate in the regulation of podocyte function. Some previous studies have shown that activation of lysosomal acid ceramidase (Ac), an essential protein consisting of a nonglycosylated $\alpha$ subunit and a glycosylated $\beta$ subunit that metabolizes ceramide within cells, protects podocytes from oxidative stress and apoptosis under pathologic conditions. ${ }^{4}$ Mutations in the AC gene $(A S A H 1)$ or deficiency of lysosomal AC activity in human cells

Supported by NIH grants DK054927 (P.-L.L.) and DK102539 (J.K.R. and P.-L.L.). 
were found to be a major genetic or pathogenic mechanism for the development of Farber disease, which features hoarseness and painful swollen joints accompanied by nephropathy with elevated urine ceramide levels as characteristic features. ${ }^{5}$ More recently, the deficiency of sphingosine-1-phosphate (S1P) lyase in humans and mice has been reported to increase S1P and ceramide levels in blood or tissues, which results in steroidresistant nephrotic syndrome (NS) with mesangial hypercellularity, glomerular hypertrophy, and glomerular fibrosis. ${ }^{6-9}$ Although the latter studies support that ceramide and associated sphingolipids may play a crucial role in the development of glomerular disease, they do not address the specific role of ceramide and associated sphingolipids in podocytes because of the global nature of the gene mutation, gene deletion, or pharmacologic interventions. These previous results do, however, constitute a sound scientific premise for investigating the importance of lysosomal Ac sphingolipid signaling in the control of podocyte function and in the development of podocytopathy.

In the present study, we used podocyte-specific Ac gene deletion strategy to investigate the contribution of podocyte Ac-associated sphingolipids to its function regulation and related disease. A podocyte-specific Ac gene knockout mouse strain using Asah1 floxed mice with podocin promoter-driven Cre (Asahl ${ }^{\mathrm{f} / \mathrm{fl}} / \mathrm{Podo}{ }^{\mathrm{Cre}}$; Asah1 is mouse code of Ac gene) and their littermates, including wild-type (WT/WT) or Asah1 floxed mice without Cre $\left(A s a h l^{\mathrm{f} / \mathrm{fl}} / \mathrm{Podo}^{\mathrm{wt}}\right)$ mice were generated, which were characterized and confirmed using a range of genetic, histologic, and biochemical analyses. Then, we examined whether these Asaht $1^{\mathrm{f} / \mathrm{f} / \mathrm{Podo}}{ }^{\mathrm{Cre}}$ mice developed podocytopathy and associated NS or glomerular sclerosis by analysis of proteinuria and albuminuria and by examination of glomerular morphologic changes using light and transmission electron microscopy (TEM). Using liquid chromatography-tandem mass spectrometry (LC-MS/MS) analysis, we defined the role of increased ceramide levels in the development of podocytopathy in Asahl $1^{\mathrm{f} / \mathrm{fl}} / \mathrm{Podo}{ }^{\mathrm{Cre}}$ mice. We also tested whether this podocytopathy or NS in Asahl $\mathrm{f}^{\mathrm{t} / \mathrm{fl} /}$ Podo $^{\mathrm{Cre}}$ mice is sensitive to steroid treatment and addressed whether podocytes in these mice have altered insulin resistance, which may contribute to podocyte injury. Finally, we knocked out their acid sphingomyelinase gene (Smpdl) in Asah $1^{\mathrm{t} / \mathrm{fl}} / \mathrm{Podo}^{\mathrm{Cre}}$ mice to generate a double deletion of Smpdl and Asahl gene in podocyte to test whether podocytopathy and associated nephrotic syndrome can be reversed. Our results demonstrate that podocyte-specific deletion of Asahl gene induces a steroid-resistant NS because of podocytopathy, and ceramide accumulation in glomeruli is a critical mechanism mediating the development of NS.

\section{Materials and Methods}

\section{Animals}

Podocyte-specific Cre recombinase (Podo ${ }^{\mathrm{Cre}}$ ) mice were obtained from the Jackson Laboratory [Bar Harbor, ME;
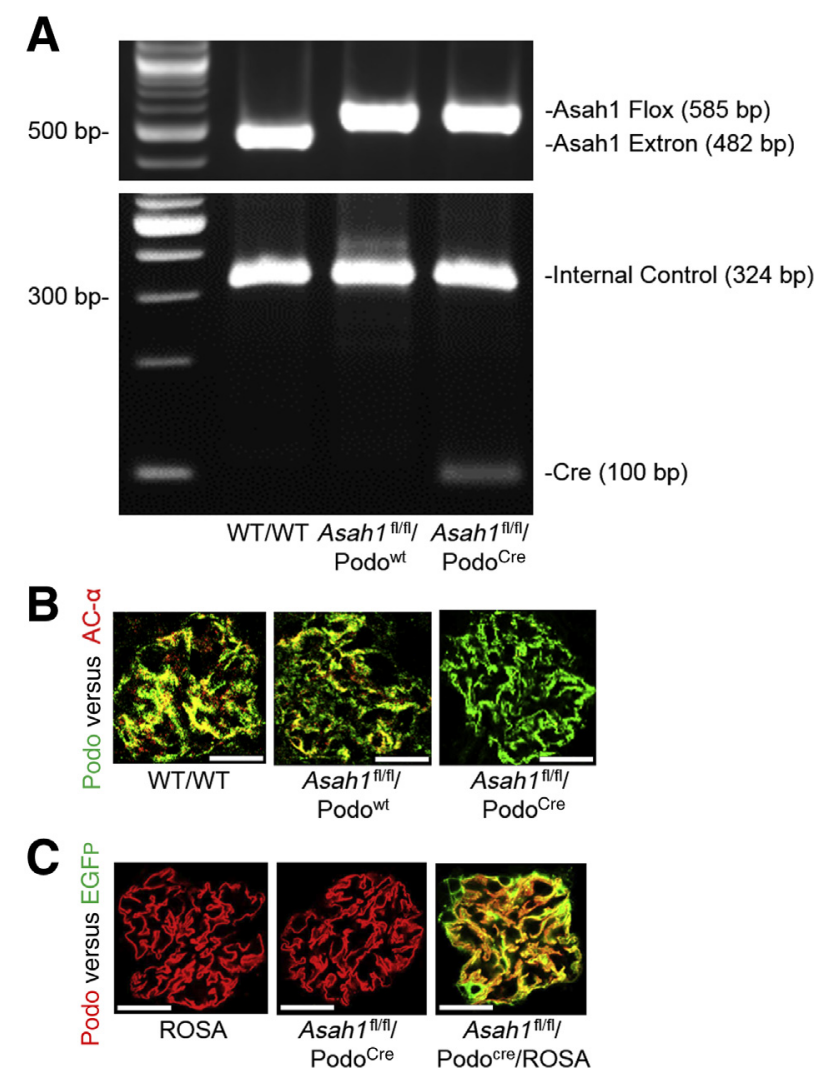

Figure 1 Characterization of $A s a h 1^{\mathrm{fl} / \mathrm{fl}} / \mathrm{Podo}^{\mathrm{Cre}}$ mice. A: Representative gel showing detection of floxed Asah1 gene and Cre recombinase gene by PCR genotyping. B: Representative images showing the colocalization of podocin (green fluorescence) and Ac $\alpha$ subunit (red fluorescence) in glomeruli of different groups of mice. C: Representative images showing the colocalization of enhanced green fluorescence protein (EGFP; green fluorescence) and podocin (red fluorescence) in glomeruli of different groups of mice. $n=6$ (B and C). Scale bars $=50 \mu \mathrm{m}$ (B and C).

B6.Cg-Tg(NPHS2-Cre)295Lbh/J; stock number 008205]. The mice carrying the floxed Ac $\alpha$ subunit construct were obtained from Erich Gulbins (University of Duisburg-Essen, Essen, Germany). The Asah $1^{\mathrm{f} / \mathrm{fl}} / \mathrm{Podo}^{\mathrm{Cre}}$ mice and their littermates were on a C57/B16 background. Urine samples were collected from the Asahl ${ }^{\mathrm{f} / \mathrm{fl}} / \mathrm{Podo}^{\mathrm{Cre}}$ mice and their littermates at the indicated time. Four-week-old WT/WT mice and $A s a h I^{\mathrm{t} / \mathrm{fl}} / \mathrm{Podo}^{\mathrm{Cre}}$ mice received daily i.p. injection of dexamethasone phosphate ${ }^{10}$ (Cayman Chemical, Ann Arbor, MI) at $5 \mathrm{mg} / \mathrm{kg}$ or metformin hydrochloride ${ }^{11}$ (Cayman Chemical) at $200 \mathrm{mg} / \mathrm{kg}$ for 4 weeks.

\section{Isolation of Glomeruli for LC-MS/MS}

For quantitation of ceramide and its products, Asahl ${ }^{\mathrm{f} / \mathrm{fl} /}$ Podo ${ }^{\mathrm{Cre}}$ mice and their littermates were used to isolate glomeruli of the kidney, as described previously. ${ }^{12,13}$ In brief, the mice were anesthetized with $2 \%$ isoflurane and then the kidneys were perfused with ice-cold phosphatebuffered saline and harvested. After blood samples were taken, the mice were euthanized. The harvested kidneys were hemisected on a sagittal plane; and the renal cortex 
was separated from the medulla, chopped into fine pieces, and passed through filters with decreasing pore sizes from 150 to $106 \mu \mathrm{m}$ (US standard sieve numbers 100 and 140, respectively; Thermo Fisher Scientific, Waltham, MA) into a petri dish. The glomeruli were captured on a $70-\mu \mathrm{m}$ cell strainer (BD Biosciences, San Jose, CA), then washed off from the sieve with ice-cold Hanks solution containing 6\% bovine serum albumin (BSA), and pelleted for later use to measure ceramide and sphingosine levels by LC-MS/MS.

\section{LC-MS/MS Analysis}

Glomeruli were isolated from mice as described above. After homogenization of glomeruli, C12 ceramide (10 ng) was added to the homogenate reaction mixture as an internal standard. Then, the mixture was separated in chloroform/ methanol/water (2:2:1.8). After evaporation with nitrogen and reconstitution with ethanol/formic acid (99.8:0.2), the samples were ready for LC-MS/MS assay. The separation of ceramide was performed on a Shimadzu SCL HPLC system (Kyoto, Japan) with a C18 Nucleosil AB Column (Macherey-Nagel, Duren, Germany). MS detection was performed using an Applied Bio Systems 3200 Q trap with a turbo V source for TurbolonSpray (Concord, ON, Canada). The concentrations of total ceramide, including C14, C16, C18, C20, C22, and C24 ceramide, and sphingosine were calculated after normalization with glomerular numbers of each sample. The fragment ion obtained with the highest mass/charge ratio $(\mathrm{m} / \mathrm{z} 264)$ was selected for quantitative MS detection in the multiple reaction monitoring mode.

\section{Mouse Genotyping}

Each mouse used in the in vivo studies was genotyped for the $A s a h 1^{\mathrm{f} / / \mathrm{fl}}$ gene and Cre recombinase gene to confirm podocyte-specific gene deletion of acid ceramidase $\alpha$ subunit before use in experiments. Briefly, genomic DNA extracted from the tail was subjected to PCR amplification using taq DNA polymerase (Invitrogen Inc., Grand Island, NY). Using a Bio-Rad iCycler (Bio-Rad, Hercules, CA), PCR was performed using a validated protocol provided by Jackson Laboratory: denaturing the DNA at $94^{\circ} \mathrm{C}$ for 3 minutes, followed by a first round of 12 cycles: $94^{\circ} \mathrm{C}$ for 20 seconds, $64^{\circ} \mathrm{C}$ for 30 seconds $\left(-0.5^{\circ} \mathrm{C}\right.$ per cycle), $72^{\circ} \mathrm{C}$ for 35 seconds, and then a second round of 25 cycles: $94^{\circ} \mathrm{C}$ for 20 seconds, $58^{\circ} \mathrm{C}$ for 30 seconds, $72^{\circ} \mathrm{C}$ for 35 seconds, and a final extension step at $72^{\circ} \mathrm{C}$ for 2 minutes. The Asahl $I^{w t}$ and $A s a h I^{f l / f}$ genes were detected using primers of $5^{\prime}$-ACAACTGTGTAGGATTCACGCATTCTCC-3' (forward) and 5'-TCGATCTATGAAATGTCGCTGTCGG-3' (reverse). The internal control gene was detected using primers of 5'-CTAGGCCACAGAATTGAAAGATCT-3' (forward) and 5'-GTAGGTGGAAATTCTAGCATCATCC- $3^{\prime}$ (reverse). The Cre recombinase gene was detected using primers of $5^{\prime}$ GCGGTCTGGCAGTAAAAACTATC-3' (forward) and 5' GTGAAACAGCATTGCTGTCACTT- $3^{\prime}$ (reverse). The
PCR products were separated by gel electrophoresis on a $3 \%$ agarose gel, visualized by ethidium bromide fluorescence, and compared with a 100-bp DNA ladder (New England Biosystems, Ipswich, MA).

\section{Immunofluorescence Microscopy}

Frozen mouse kidney sections were fixed in acetone, blocked, then incubated with the same aforementioned
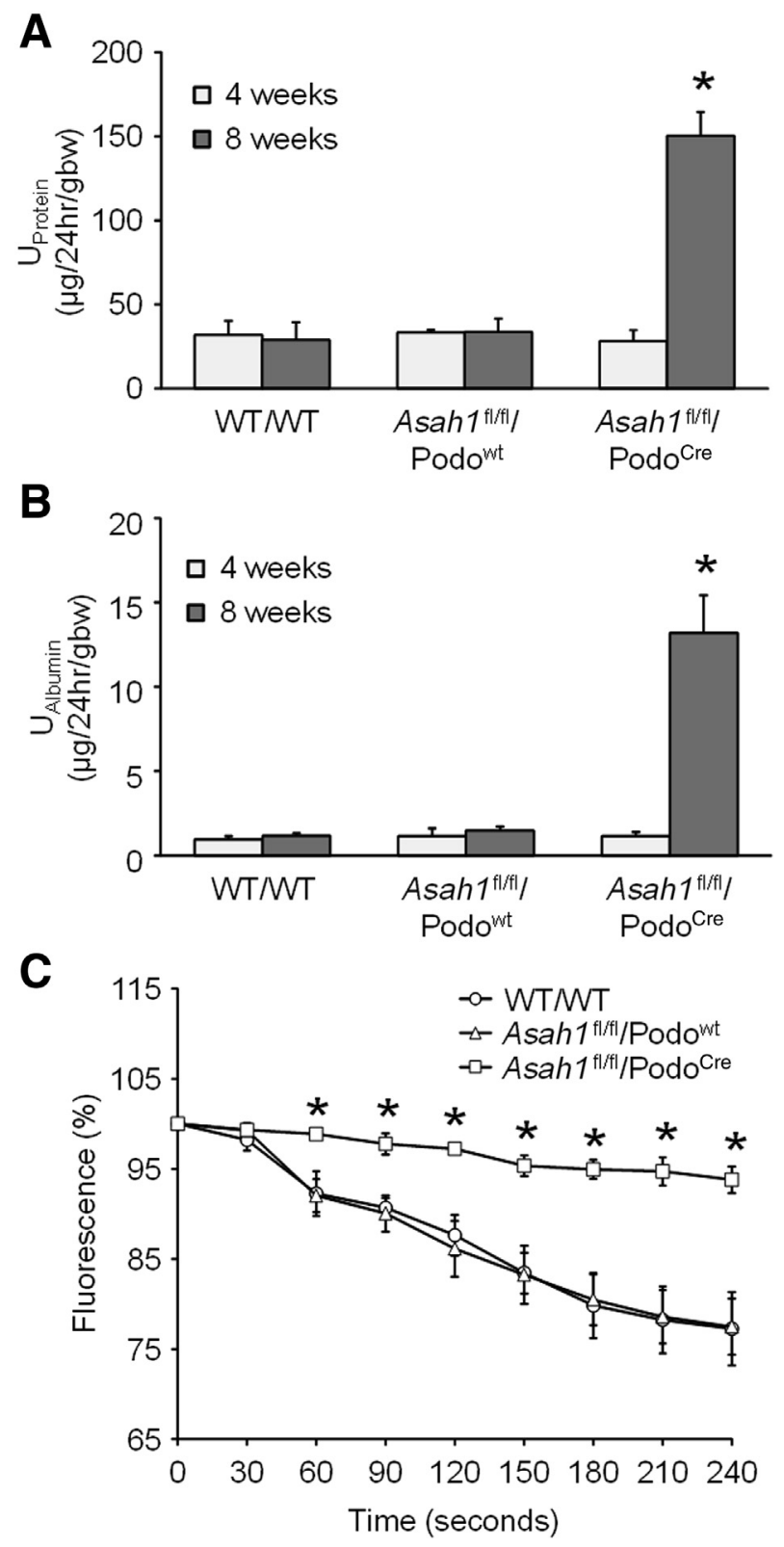

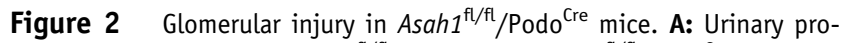

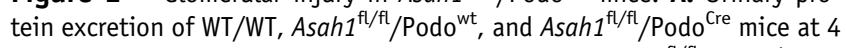
and 8 weeks. B: Urinary albumin excretion of WT/WT, Asah $1^{\mathrm{fl} / \mathrm{fl} /} / \mathrm{Podo}^{\mathrm{wt}}$, and Asah $1^{\mathrm{fl} / \mathrm{fl}} / \mathrm{Podo}^{\mathrm{Cre}}$ mice at 4 and 8 weeks. C: Changes in fluorescence intensity in glomeruli isolated from Asah $1^{\mathrm{fl} / \mathrm{fl} / \mathrm{Podo}^{\mathrm{Cre}}}$ mice and their littermates at 8 weeks old. $n=5$ to $12(\mathbf{A}) ; n=5$ to $10(\mathbf{B}) ; n=4$ to 6 (C). ${ }^{*} P<0.05$ versus WT/WT. EGFP, enhanced green fluorescence protein. 
A

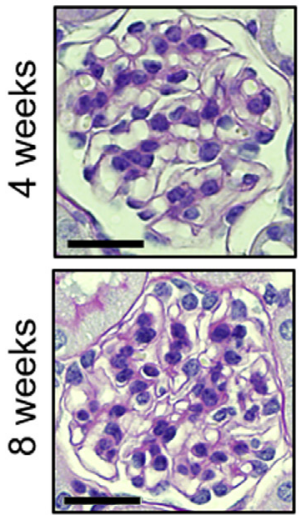

WT/WT
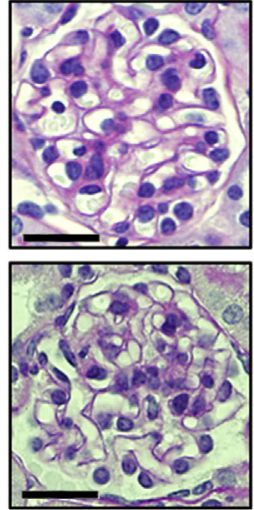

Asah $1^{\text {fl/fi/ }}$

Podowt
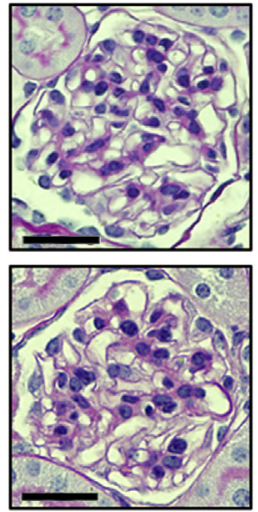

Asah1 $1^{\mathrm{fl} / \mathrm{fl} /}$

PodoCre
B

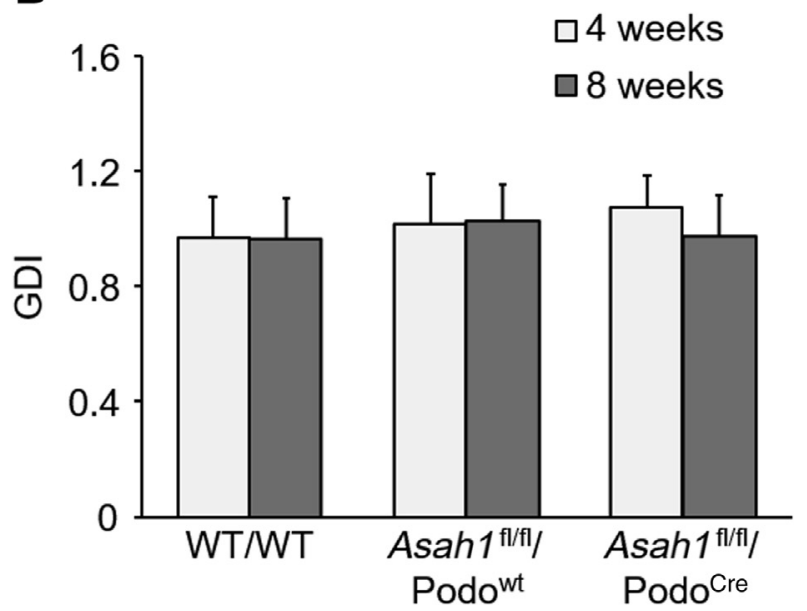

Figure 3 Undetectable glomerular morphologic changes in $A s a h 1^{\mathrm{fl} / \mathrm{fl}} / \mathrm{Podo}^{\mathrm{Cre}}$ mice under light microscope. A: Representative images showing the glomerular morphologic changes (periodic acid-Schiff staining) of different groups of mice. B: Summarized data of glomerular damage indexes (GDIs) of different groups of mice. $n=6(\mathbf{B})$. Scale bars $=50 \mu \mathrm{m}(\mathbf{A})$.

primary antibodies overnight at $4^{\circ} \mathrm{C}$. Some coverslips with frozen kidney sections were stained for podocin $(1: 100$; Sigma-Aldrich, St. Louis, MO). Immunofluorescence staining was performed by Alexa Fluor 488- or Alexa Fluor 555-labeled secondary antibody (1:200; Invitrogen, Carlsbad, CA) incubation for 1 hour at room temperature. Slides were then washed, mounted, and observed using a confocal laser scanning microscope (FluoView FV1000; Olympus, Tokyo, Japan).

\section{Urinary Protein and Albumin Measurements}

Total urinary protein excretion was determined spectrophotometrically using the Bradford assay (Sigma-Aldrich), and urinary albumin excretion was measured using a commercially available mouse albumin enzyme-linked immunosorbent assay kit (Bethyl Laboratories, Montgomery, TX).

\section{Glomerular Morphologic Examination}

Renal tissues were fixed with a $10 \%$ formalin solution, paraffin embedded, and stained with periodic acid-Schiff. Renal morphology was observed using a light microscope, and glomerular sclerosis was assessed semiquantitatively and expressed as glomerular damage index. ${ }^{14,15}$ Fifty glomeruli per slide were counted and scored as $0,1,2,3$, or 4 , according to $0 \%,<25 \%, 25 \%$ to $50 \%, 51 \%$ to $75 \%$, or $>75 \%$ sclerotic changes, respectively, across a longitudinal kidney section. The glomerular damage index for each mouse was calculated by the formula $[(\mathrm{N} 1 \times 1)+(\mathrm{N} 2 \times 2)+(\mathrm{N} 3 \times 3)+(\mathrm{N} 4 \times 4)] / \mathrm{n}$, where $\mathrm{N} 1, \mathrm{~N} 2, \mathrm{~N} 3$, and $\mathrm{N} 4$ represent the numbers of glomeruli exhibiting grades $1,2,3$, and 4 , respectively, and $n$ is the total number of glomeruli scored.

\section{TEM Data}

For TEM analysis of ultrastructural changes in podocytes, mouse kidneys were perfused with a fixative containing $3 \%$ glutaraldehyde and $4 \%$ paraformaldehyde in $0.1 \mathrm{~mol} / \mathrm{L}$ phosphate buffer. After fixation and dehydration with ethanol, the samples were embedded in Durcupan resin for ultrathin sectioning by the Virginia Commonwealth University microscopy core facility. ${ }^{16}$

\section{Immunohistochemistry}

Kidneys were embedded with paraffin, and sections $(5 \mu \mathrm{m}$ thick) were cut from the embedded blocks. After heat-induced antigen retrieval, washing with $3 \% \mathrm{H}_{2} \mathrm{O}_{2}$, and 30 minutes blocking with fetal bovine serum, slides were incubated with primary antibody diluted in phosphate-buffered saline with 4\% fetal bovine serum. Anti- $\alpha$-dystroglycan antibody (Santa Cruz Biotechnology, Dallas, TX) and anti- $\beta$-dystroglycan antibody (Santa Cruz Biotechnology) were used as primary antibodies in this study. After incubation with primary antibody overnight, the sections were washed in phosphatebuffered saline and incubated with biotinylated $\operatorname{IgG}(1: 200)$ for 1 hour and then with streptavidin-horseradish peroxidase for 30 minutes at room temperature. Diaminobenzidine (50 $\mu \mathrm{L}$ ) was added to each kidney section and stained for 1 minute. After washing, the slides were counterstained with hematoxylin for 5 minutes. The slides were then mounted and observed under a microscope in which images were taken. ${ }^{17,18}$

\section{Glucose Tolerance Test}

An oral glucose tolerance test was performed following fasting for 14 hours. Plasma glucose concentrations were measured in blood samples that were taken from the tail using glucose meter at $0,30,60,120$, and 180 minutes after administration of glucose $(3 \mathrm{~g} / \mathrm{kg}){ }^{19}$ 
A Foot Process Effacement

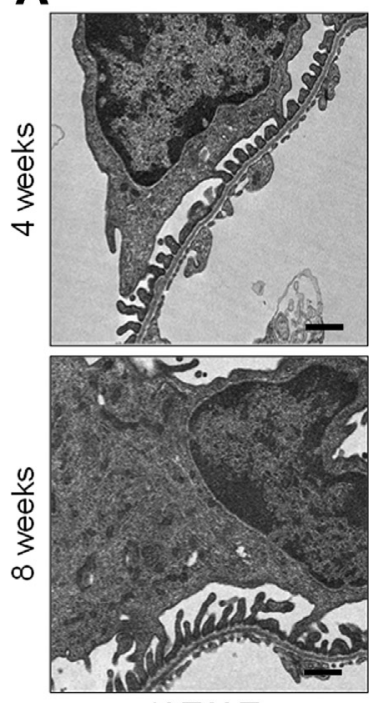

WTNT

B Microvilli

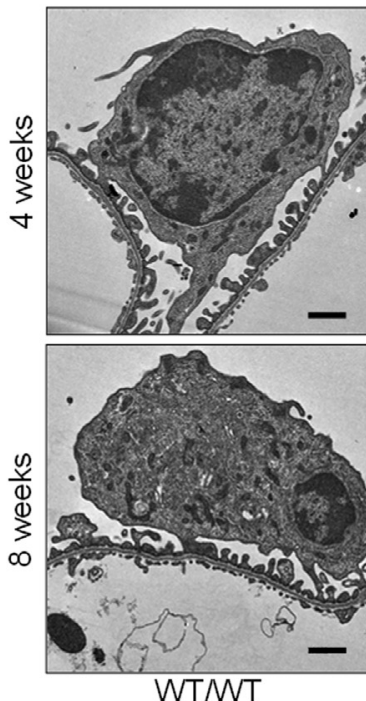

WTMT
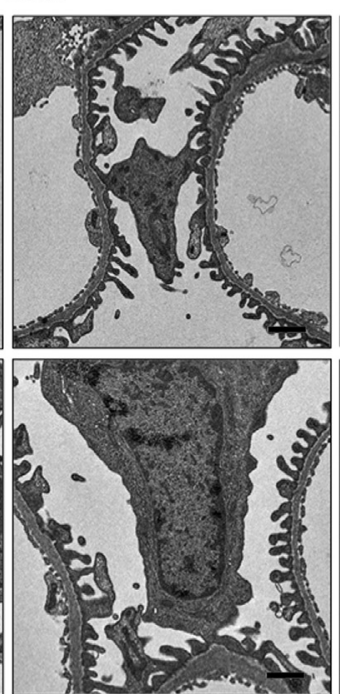

Asah $1^{\text {ffffl/Podo }}$ int
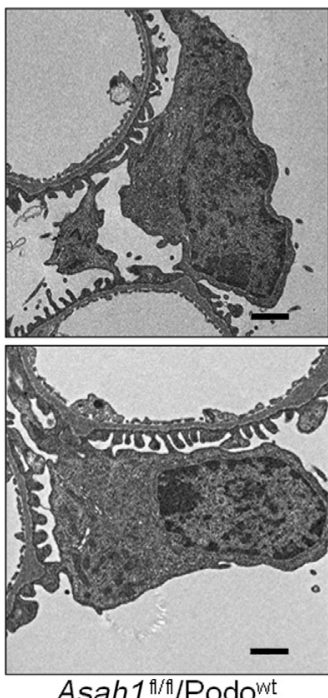

Asah1 1//1/Podowt
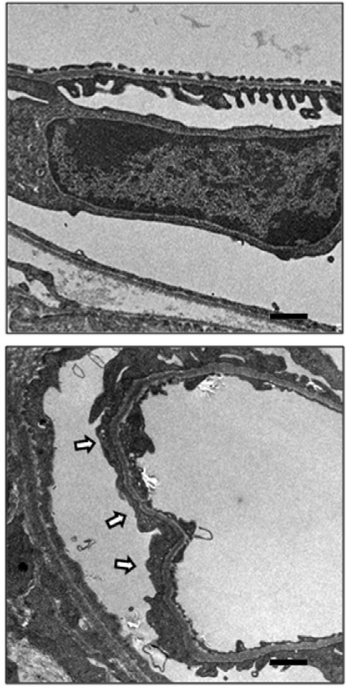

Asah $1^{\mathrm{fl} / \mathrm{fl} / \mathrm{Podo} \mathrm{Cre}}$

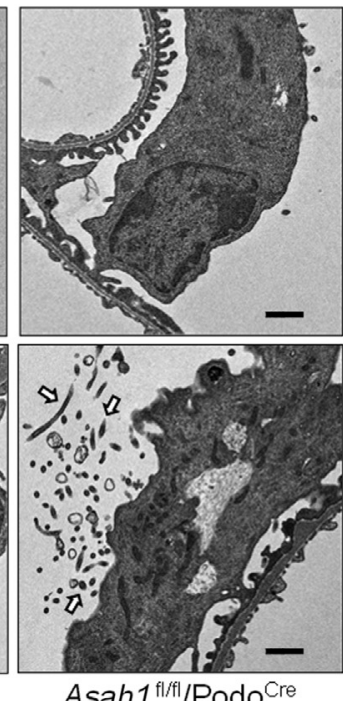

Figure 4 Ultrastructural changes in podocytes of mice carrying podocyte-specific gene deletions in the $\alpha$ subunit of acid ceramidase (Asah $1^{\mathrm{fl} / \mathrm{fl} / \mathrm{Podo}^{\text {Cre }}}$ ). A: Representative electron microscopic images showing foot processes in podocytes from Asah $1^{\mathrm{fl} / \mathrm{fl}} / \mathrm{Podo}^{\mathrm{Cre}}$ mice and control genotype littermates at 4 or 8 weeks of age. The foot process effacement (arrows) was observed in podocytes of Asah $1^{\mathrm{fl} / \mathrm{fl}} /$ Podo $^{\text {Cre }}$ mice at 8 weeks. B: Representative images showing microvilli of podocytes in $A s a h 1^{\mathrm{fl} / \mathrm{fl}} / \mathrm{Podo}^{\mathrm{Cre}}$ mice and their littermates at different ages. The microvilli (arrows) were observed in podocytes of $A s a h 1^{\mathrm{fl} / \mathrm{fl}} / \mathrm{Podo}^{\mathrm{Cre}}$ mice at 8 weeks. $n=4(\mathbf{A}$ and $\mathbf{B})$. Scale bars $=1 \mu \mathrm{m}(\mathbf{A}$ and $\mathbf{B}$ ).

\section{Statistical Analysis}

All the values are expressed as means \pm SEM. Significant differences among multiple groups were examined using analysis of variance, followed by a Student-Newman-Keuls test. $P<0.05$ was considered statistically significant.

\section{Results}

Characterization of Podocyte-Specific Gene Deletion of Ac $\alpha$ Subunit in Asah $1^{\mathrm{fl} / \mathrm{fl} / \text { Podo }}{ }^{\text {Cre }}$ Mice

To investigate the physiological relevance of Ac inhibition or ceramide metabolism in podocytes for glomerular function, a mouse model with podocyte-specific Ac gene knockout was generated, which is designated the Asahl $1^{\mathrm{f} / \mathrm{fl}} / \mathrm{Podo}{ }^{\mathrm{Cre}}$ mouse colony (Asah1 is Ac gene code in mice). These mice and their littermates were characterized using several genetic, molecular, and biochemical approaches. Detection of only the floxed Asahl and Cre recombinase gene alleles upon PCR genotyping indicated homozygosity for both genes, whereas if neither floxed Asahl gene nor Cre recombinase sequences were detected, the mice were wild type at both loci (WT/WT) (Figure 1A). If only floxed Asahl gene was detected without Cre recombinase gene, the mice were Asahl floxed gene controls without podocyte-specific deletion (Asahl $l^{\mathrm{f} / \mathrm{fl}}$ / Podo $^{\mathrm{wt}}$ ). Confocal microscopy showed no colocalization of the podocyte marker, podocin (green fluorescence), and the Ac $\alpha$ subunit (red fluorescence) in glomeruli of $A s a h 1^{\mathrm{f} / \mathrm{fl}} / \mathrm{Podo}^{\mathrm{Cre}}$ mice, compared with WT/WT and $A s a h l^{\mathrm{f} / / \mathrm{f} / \mathrm{WT}}$ mice. This indicates podocyte-specific gene deletion of Ac $\alpha$ subunit in glomeruli of $A s a h 1^{\mathrm{f} / \mathrm{fl}} / \mathrm{Podo}{ }^{\mathrm{Cre}}$ mice (Figure 1B). To further 


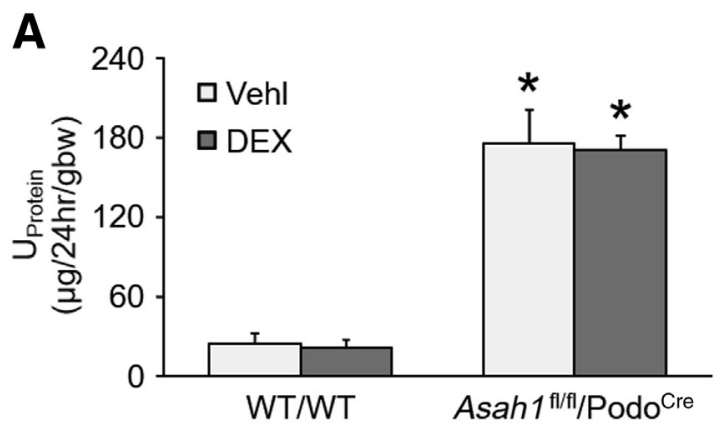

B

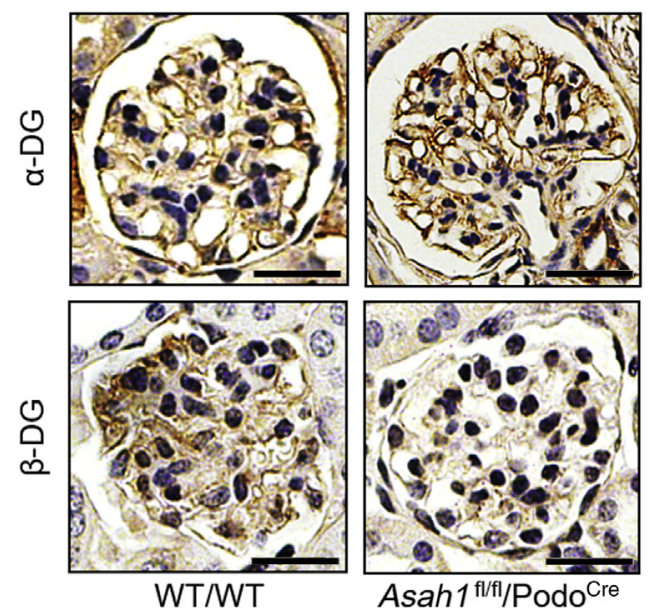

C

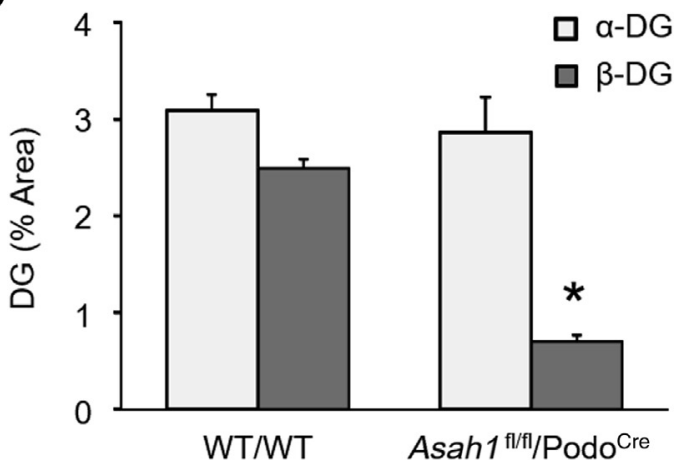

Figure 5 Failure of corticosteroid to reverse nephrotic syndrome in Asah $1^{\mathrm{fl} / \mathrm{fl} /} / \mathrm{Podo}^{\mathrm{Cre}}$ mice. A: Urinary protein (U $\mathrm{U}_{\text {Protein }}$ ) excretion of WT/WT and Asah $1^{\mathrm{fl} / \mathrm{fl}} / \mathrm{Podo}^{\mathrm{Cre}}$ mice with treatments of vehicle or dexamethasone phosphate. B: Representative images showing the glomerular expression of $\alpha$-dystroglycan $(\alpha-D G)$ and $\beta$-dystroglycan $(\beta-D G)$ in WT/WT and $A s a h 1^{\mathrm{fl} / \mathrm{fl}} /$ Podo ${ }^{\text {Cre }}$ mice. C: Summarized data showing the glomerular expression of $\alpha$ dystroglycan and $\beta$-dystroglycan in WT/WT and $A s a h 1^{\mathrm{fl} / \mathrm{fl}} / \mathrm{Podo}^{\mathrm{Cre}}$ mice. $n=5$ to 6 (A); $n=4$ (C). ${ }^{*} P<0.05$ versus WT/WT-vehicle. Scale bars $=50 \mu \mathrm{m}(\mathbf{B}) . \mathrm{gbw}$, gram of body weight.

confirm the tissue-specific Asahl gene deletion in podocytes, $A s a h 1^{\mathrm{f} / \mathrm{fl}} / \mathrm{Podo}{ }^{\mathrm{Cre}}$ mice were mated with ROSA mice to produce $A s a h 1^{\mathrm{f} / \mathrm{fl}} / \mathrm{Podo}^{\mathrm{Cre}} / \mathrm{ROSA}$ mice. Using confocal microscopy, the expression of enhanced green fluorescence protein was analyzed in the glomeruli of $A s a h 1^{\mathrm{f} / \mathrm{fl}} / \mathrm{Podo}^{\mathrm{Cre}}$ mice and their littermates. Although the green fluorescence emitted by enhanced green fluorescence protein was undetectable in $A s a h 1^{\mathrm{f} / \mathrm{fl}} / \mathrm{Podo}{ }^{\mathrm{Cre}}$ or ROSA mice, colocalization of enhanced green fluorescence protein (green fluorescence) and podocin (red fluorescence) was remarkable in glomeruli of $A s a h 1^{\mathrm{f} / \mathrm{fl}}$ / Podo $^{\mathrm{Cre}} / \mathrm{ROSA}$ mice (Figure 1C). This is because expression of enhanced green fluorescence protein was activated when two types of mouse strains were crossbred. Altogether, these results confirm podocyte-specific deletion of Ac gene in Asaht $^{\mathrm{t} / \mathrm{f} /} / \mathrm{Podo}^{\mathrm{Cre}}$ mice.

\section{Glomerular Injury Induced by Podocyte-Specific Gene Deletion of Ac $\alpha$ Subunit}

To determine whether podocyte-specific gene deletion of Ac $\alpha$ subunit induces podocyte dysfunction and glomerular injury, urinary protein and albumin excretion were measured per 24 hours in the WT/WT, $A s a h 1^{\mathrm{f} / \mathrm{fl}} / \mathrm{Podo}^{\mathrm{wt}}$, and $A s a h 1^{\mathrm{f} / \mathrm{fl}} / \mathrm{Podo}^{\mathrm{Cre}}$ mice. No significant differences were found in urinary protein and albumin excretion between 4-week-old Asahl $1^{\mathrm{f} / 1 / 1} / \mathrm{Podo}^{\mathrm{Cre}}$ mice and their littermates (Figure 2, A and B). However, in 8week-old mice, severe proteinuria and albuminuria were found in Asaht ${ }^{\mathrm{fl} / \mathrm{fl}} / \mathrm{Podo}^{\mathrm{Cre}}$ mice compared with WT/WT and Asah $1^{\mathrm{t} / \mathrm{f} /} / \mathrm{Podo}^{\mathrm{wt}}$ mice. Proteinuria and albuminuria were not detected in Podo ${ }^{\mathrm{Cre}}$ mice (data not shown). These data indicate that podocyte-specific gene deletion of the Ac $\alpha$ subunit induces serious glomerular injury, leading to proteinuria and albuminuria.

In addition, glomerular permeability to albumin of WT/WT, Asah $1^{\mathrm{f} / \mathrm{fl} /} / \mathrm{Podo}^{\mathrm{wt}}$, and $A \operatorname{sah} 1^{\mathrm{f} / \mathrm{fl} /} / \mathrm{Podo}^{\mathrm{Cre}}$ mice was measured, as previously described. ${ }^{20}$ Glomeruli were isolated in an isotonic Hanks' balanced salt solution containing $6 \%$ BSA. Following a rapid change in the concentration of the bath from $6 \%$ BSA to $4 \% \mathrm{BSA}$, an oncotic gradient of approximately $9 \mathrm{mmHg}$ was generated. This oncotic gradient drove water into the glomerular capillaries, which leads to reduction of the concentration and fluorescence intensity of the fluorescein isothiocyanate-dextran in the glomerular capillaries. This oncotic pressure-dependent fluid movement within glomeruli can be used for measurement of glomerular filtration membrane permeability. The intensities of fluorescence in glomeruli isolated from WT/WT and Asahl $I^{\mathrm{f} / \mathrm{fl}} / \mathrm{Podo}^{\mathrm{wt}}$ mice were markedly decreased after the rapid change in BSA bath concentration from $6 \%$ to $4 \%$ (Figure 2C). This indicates the movement of water into glomerular capillaries of WT/WT and $A s a h l^{\mathrm{f} / \mathrm{fl} /}$ Podo $^{\mathrm{wt}}$ mice and normal permeability with intact barrier for generation of oncotic pressure. In contrast, there were almost no changes in intensity of fluorescence in glomeruli isolated from Asahl $1^{\mathrm{f} / \mathrm{fl}} / \mathrm{Podo}^{\mathrm{Cre}}$ mice after formation of the oncotic gradient. This indicates oncotic molecules are balanced across the glomerular filtration membrane and a loss of the driving force for water to move into the capillaries, leading to increased glomerular permeability to albumin in $A s a h 1^{\mathrm{f} / / \mathrm{fl}} / \mathrm{Podo}^{\mathrm{Cre}}$ mice.

\section{Podocyte Injury in Asah $1^{\mathrm{fl} / \mathrm{fl}} / \mathrm{Podo}^{\text {Cre }}$ Mice}

Morphologic examination by periodic acid-Schiff staining showed no remarkable sclerotic changes, such as mesangial expansion, collapse of glomerular capillaries, or 
A

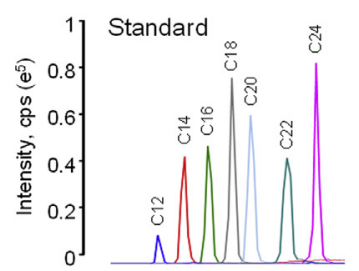

B

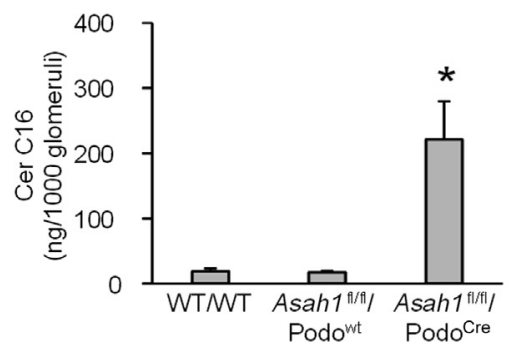

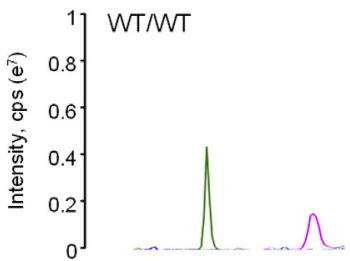

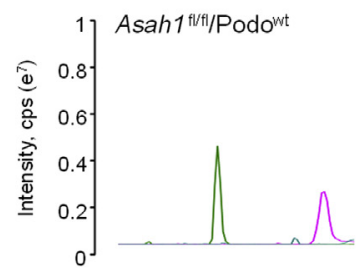

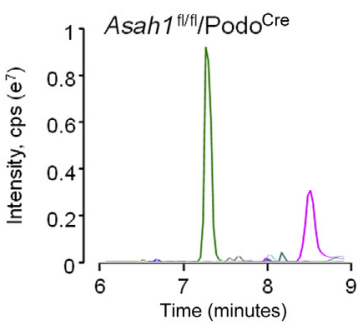

D

Figure 6 Ceramide (Cer) accumulation in glomeruli of $A s a h 1^{\mathrm{fl} / f l} / \mathrm{Podo}^{\mathrm{Cre}}$ mice. A: Representative multiple reaction monitoring chromatography of ceramides separated by liquid chromatography-tandem mass spectrometry. B: Summarized data showing the levels of C16 ceramide in isolated glomeruli of different groups of mice. C: Summarized data showing the levels of total ceramide in isolated glomeruli of different groups of mice. D: Summarized data showing the levels of sphingosine (Sph) in isolated glomeruli of different groups of mice. $n=4$ to 6 (B-D). ${ }^{*} P<0.05$ versus WT/WT. cps, counts per second; Cre, Cre recombinase.

hypercellularity in glomeruli of $A s a h 1^{\mathrm{f} / \mathrm{fl}} / \mathrm{Podo}^{\mathrm{Cre}}$ mice. There was no significant increase in glomerular damage index of $A s a h 1^{\mathrm{f} / \mathrm{fl}} / \mathrm{Podo}{ }^{\mathrm{Cre}}$ mice compared with their littermates at both 4 and 8 weeks (Figure 3). Using transmission electron microscopy, no remarkable changes in podocytes were evident in $A s a h 1^{\mathrm{fl} / \mathrm{fl}} / \mathrm{Podo}^{\mathrm{Cre}}$ mice compared with their littermates at 4 weeks of age. However, at 8 weeks, Asah $1^{\mathrm{f} / \mathrm{fl}}$ / Podo ${ }^{\mathrm{Cre}}$ mice had critical foot process effacement in podocytes compared with their littermates (Figure 4A). In addition, microvillus formation was observed on the membrane of podocytes in 8-week-old Asahl $1^{\mathrm{f} / \mathrm{fl}} / \mathrm{Podo}^{\mathrm{Cre}}$ mice but not in their control littermates (Figure 4B).

\section{Failure of Corticosteroid to Reverse Nephrotic Syndrome in Asah $^{\mathrm{fl} / \mathrm{fl}} / \mathrm{Podo}^{\text {Cre }}$ Mice}

Mechanistically, the possibility that the nephrotic syndrome developed in Asaht $1^{\mathrm{f} / \mathrm{fl}} / \mathrm{Podo}^{\mathrm{Cre}}$ mice would be sensitive to steroid treatment was first tested. The treatment of 4week-old AsahI $I^{\mathrm{f} / \mathrm{f} /} / \mathrm{Podo}^{\mathrm{Cre}}$ mice for 4 weeks with dexamethasone phosphate failed to reverse the proteinuria (Figure 5A). The rate of urinary protein excretion in the dexamethasone phosphate-treated group was similar to the vehicle-treated Asahl $1^{\mathrm{f} / \mathrm{fl}} / \mathrm{Podo}^{\mathrm{Cre}}$ mice. To further confirm the type of nephrotic syndrome in $A s a h 1^{\mathrm{f} / \mathrm{f}} / \mathrm{Podo}^{\mathrm{Cre}}$ mice, both $\alpha$-dystroglycan and $\beta$-dystroglycan were analyzed in glomeruli by immunohistochemistry. $\alpha$-dystroglycan was not different between WT/WT mice and Asahl $1^{\mathrm{f} / \mathrm{fl}} / \mathrm{Podo}{ }^{\mathrm{Cre}}$ mice, whereas $\beta$-dystroglycan was found to be remarkably reduced by the podocyte-specific Asahl gene deletion (Figure 5, B and C). Given that both $\alpha$-dystroglycan and $\beta$-dystroglycan were reported to decrease in steroidsensitive nephrotic syndrome, ${ }^{21}$ it was concluded that the nephrotic syndrome that developed in Asahl $1^{\mathrm{f} / \mathrm{f} /} / \mathrm{Podo}^{\mathrm{Cre}}$ mice was not steroid-sensitive nephrotic syndrome.

\section{Ceramide Accumulation in Glomeruli of $A s a h 1^{\mathrm{fl} / \mathrm{fl}} /$ Podo ${ }^{\text {Cre }}$ Mice}

To confirm whether podocyte-specific gene deletion of the Ac $\alpha$ subunit results in altered levels of either ceramide or sphingosine in podocytes, glomeruli of WT/WT, $A s a h 1^{\mathrm{f} / \mathrm{fl}} / \mathrm{Podo}^{\mathrm{wt}}$, and $A s a h 1^{\mathrm{f} / \mathrm{fl}} / \mathrm{Podo}^{\mathrm{Cre}}$ mice were isolated for sphingolipid analysis by LC-MS/MS. Figure 6A shows the representative MS chromatography of ceramide in standard and extracts of sphingolipids from glomeruli of mice with different genotypes. Seven distinct peaks corresponding to C12, C14, C16, C18, $\mathrm{C} 20, \mathrm{C} 22$, and $\mathrm{C} 24$ ceramides were detected. Total ceramide levels and C16 ceramide, the main substrate of Ac, were analyzed after normalization for the number of glomeruli collected for the analysis. It was found that both total ceramide and $\mathrm{C} 16$ ceramide levels were much higher in glomeruli of Asaht $1^{\mathrm{f} / \mathrm{fl}} / \mathrm{Podo}{ }^{\mathrm{Cre}}$ mice, compared with WT/WT and $A s a h 1^{\mathrm{f} / \mathrm{fl}} /$ WT mice (Figure 6, B and C). On the other hand, there was no significant difference in the glomerular sphingosine level among mice with different genotypes (Figure 6D).

\section{Failure of Metformin to Prevent Podocytopathy in Asah $1^{\mathrm{fl} / \mathrm{fl}} / \mathrm{Podo}^{\text {Cre }}$ Mice}

To test whether insulin resistance of podocytes was induced by podocyte-specific Asahl gene deletion, blood glucose and 

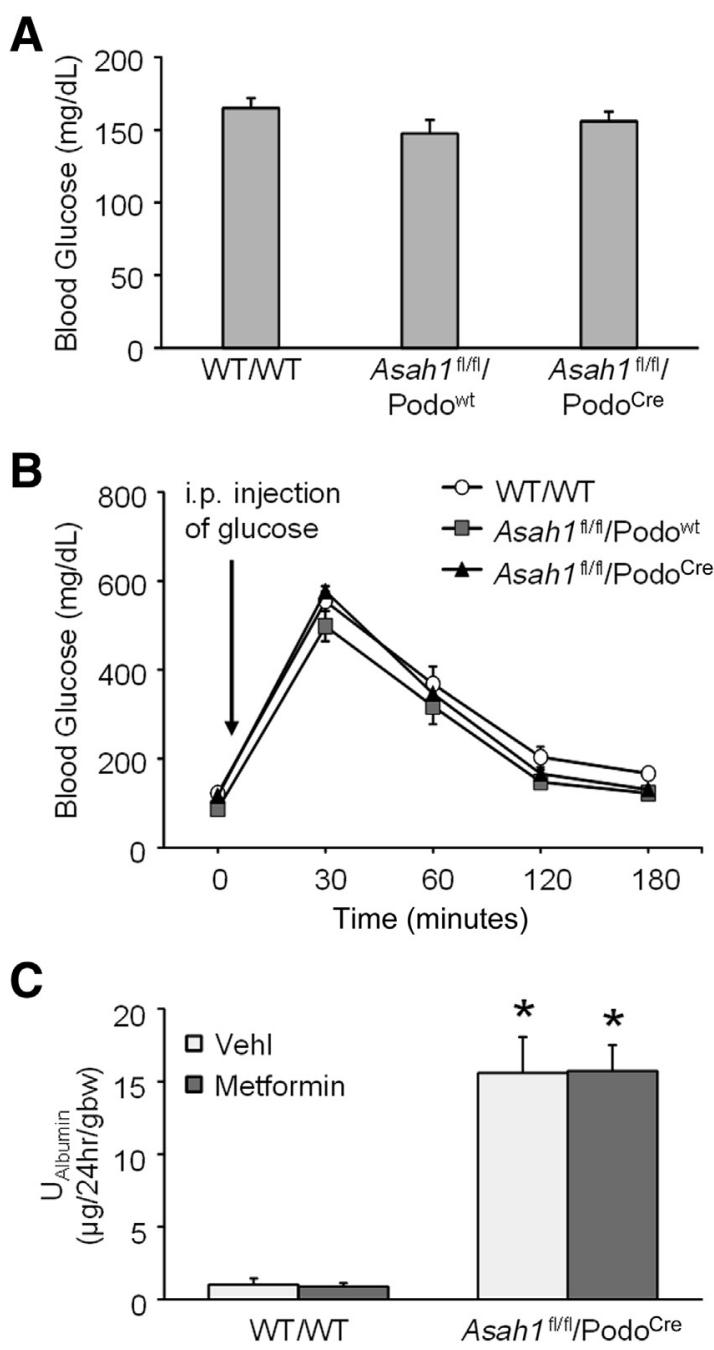

Figure 7 Failure of metformin to prevent podocytopathy in $A s a h 1^{\mathrm{fl} / \mathrm{fl}} /$ Podo ${ }^{\text {Cre }}$ mice. A: Summarized data of blood glucose in different groups of mice at 8 weeks B: Summarized data of glucose tolerance in different groups of mice at 8 weeks. C: Urinary albumin $\left(\mathrm{U}_{\text {Albumin }}\right)$ excretion of WT/WT and $A s a h 1^{\mathrm{fl} / \mathrm{fl}} / \mathrm{Podo}^{\mathrm{Cre}}$ mice with treatments of vehicle or metformin hydrochloride. $n=6$ to $17(\mathbf{A}) ; n=4$ to 6 (B); $n=5$ (C). ${ }^{*} P<0.05$ versus WT/WT-vehicle. gbw, gram of body weight.

glucose tolerance were measured in $A s a h 1^{\mathrm{f} / \mathrm{fl}} / \mathrm{Podo}{ }^{\mathrm{Cre}}$ mice and their littermates. No significant difference in blood glucose level was observed in $A s a h 1^{\mathrm{fl} / \mathrm{fl}} / \mathrm{Podo}^{\mathrm{Cre}}$ mice compared with their littermates (Figure 7A). Furthermore, Asahl ${ }^{\mathrm{f} / \mathrm{fl}} / \mathrm{Podo}^{\mathrm{Cre}}$ mice and their littermates exhibited similar responses in a glucose tolerance test (Figure 7B). In addition, the podocyte-specific Ac $\alpha$ deleted mice were also tested for their response to metformin hydrochloride, a treatment of type 2 diabetes, and no difference in the hyperalbuminuric response was observed (Figure 7C).

\section{Role of Ceramide in Glomerular Injury of $A s a h 1^{\mathrm{fl} / f l} /$ Podo ${ }^{\text {Cre }}$ Mice}

To test whether it was the accumulation of ceramide in the glomeruli that was specifically responsible for the observed podocyte injury in $A s a h 1^{\mathrm{f} / \mathrm{fl}} / \mathrm{Podo}^{\mathrm{Cre}}$ mice, $A s a h 1^{\mathrm{f} / \mathrm{fl}} / \mathrm{Podo}^{\mathrm{Cre}}$ mice were mated with $S m p d 1^{-/-}$mice to produce $S m p d 1^{-1}$ ${ }^{-} / A s a h 1^{\mathrm{f} / \mathrm{fl} /} / \mathrm{Podo}^{\mathrm{Cre}}$ mice. Considering that acid sphingomyelinase (ASM) catalyzes the breakdown of sphingomyelin to ceramide and phosphorylcholine, it was hypothesized that gene knockout of ASM may prevent ceramide accumulation induced by podocyte-specific Asahl gene deletion. The C16 ceramide level was much lower in glomeruli of $S m p d 1^{-1}$ ${ }^{-} / A s a h 1^{\mathrm{f} / \mathrm{fl}} / \mathrm{Podo}{ }^{\mathrm{Cre}}$ mice compared with $A s a h 1^{\mathrm{f} / \mathrm{fl}} / \mathrm{Podo}^{\mathrm{Cre}}$ mice (Figure 8A). The urinary protein excretion of $S m p d l^{-1}$ $-/ A s a h 1^{\mathrm{f} / / \mathrm{fl}} / \mathrm{Podo}{ }^{\mathrm{Cre}}$ mice was significantly lower than $A s a h 1^{\mathrm{f} / \mathrm{fl}} / \mathrm{Podo}{ }^{\mathrm{Cre}}$ mice at 8 weeks (Figure $8 \mathrm{~B}$ ). At 4 weeks, there were no significant differences in urinary albumin ex-

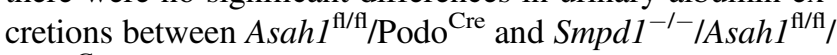

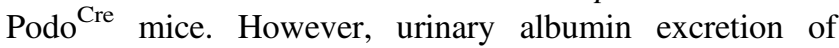
Smpd $1^{-1-} / A s a h 1^{\mathrm{f} / \mathrm{fl}} / \mathrm{Podo}^{\mathrm{Cre}}$ mice was remarkably lower than $A s a h 1^{\mathrm{f} / \mathrm{fl}} / \mathrm{Podo}{ }^{\mathrm{Cre}}$ mice at 8 weeks (Figure $8 \mathrm{C}$ ). Further analysis by TEM revealed that the Smpdl ${ }^{-1-} / A s a h 1^{\mathrm{t} / \mathrm{fl}} /$ Podo $^{\text {Cre }}$ mice did not exhibit any evident foot process effacement and formation of microvilli at 8 weeks of age in contrast to $A s a h 1^{\mathrm{f} / \mathrm{fl}} / \mathrm{Podo}^{\mathrm{Cre}}$ mice (Figure 9).

\section{Discussion}

The major objective of the present study was to determine whether lysosomal Ac activity contributes to the control of podocyte function and whether its deficiency causes glomerular disease. Toward that end, mice with a specific knockout of the Ac $\alpha$ gene in podocytes were generated and characterized, and they were found to exhibit glomerular ceramide accumulation and markers of podocyte injury consistent with podocytopathy and the development of nephrotic syndrome. Further knockout of the Smpdl gene in these mice demonstrated that it not only prevented the glomerular ceramide accumulation but also was protective in the mice against the podocyte injury associated with podocyte-specific Ac gene deletion. These results suggest that lysosomal Ac gene expression and its functional activity tonically regulate the glomerular ceramide level and thereby play essential roles in the maintenance of podocyte structural and functional integrity. The defect of Ac gene expression and its dysfunction result in podocytopathy and nephrotic syndrome.

It has been reported that podocytes in glomeruli of mammalian animals are highly differentiated and therefore the maintenance of functional and structural integrity of these cells during their long-term survival is more dependent on the normal function of lysosomes. ${ }^{22-25}$ In this regard, we recently demonstrated that lysosomal Ac activity is critical for transient receptor potential mucolipin 1 (TRPML1) channel-mediated $\mathrm{Ca}^{2+}$ release, which controls lysosome function and exosome release in podocytes. ${ }^{26}$ This led us to hypothesize that lysosomal Ac dysfunction may be an important mechanism leading to pathologic changes of podocytes, the visceral epithelial cells essential for the 

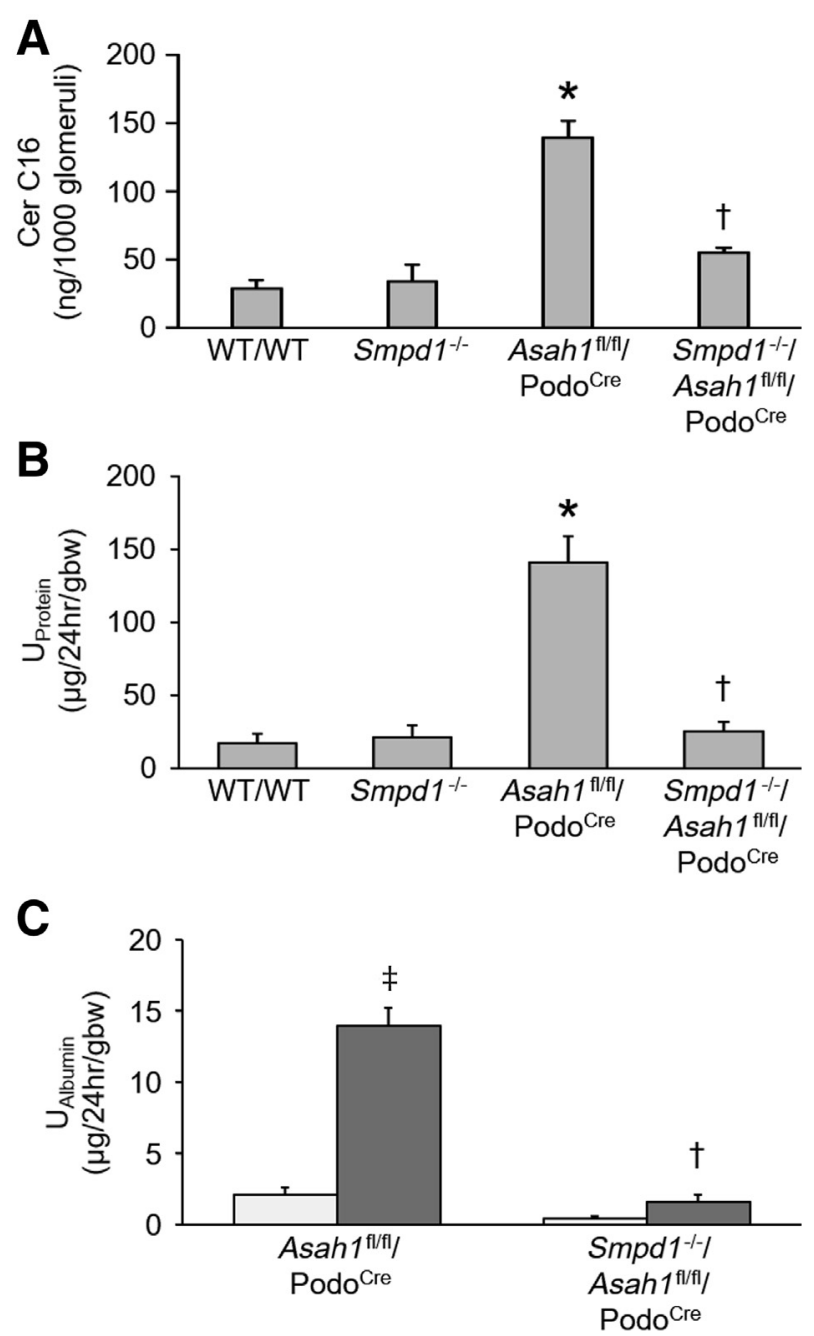

Figure 8 Attenuation of glomerular damage by global Smpd1 gene deletion. A: Summarized data showing the levels of C16 ceramide (Cer) in isolated glomeruli of different groups of mice. B: Urinary protein $\left(\mathrm{U}_{\text {Protein }}\right)$ excretion of WT/WT, Smpd1 ${ }^{-/-}$, Asah $1^{\mathrm{fl} / \mathrm{fl}} / \mathrm{Podo}^{\mathrm{Cre}}$, and Smpd1 ${ }^{-/-} /$Asah $^{\mathrm{fl} / \mathrm{fl}} / \mathrm{Podo}^{\mathrm{Cre}}$ mice at 8 weeks. C: Urinary albumin $\left(\mathrm{U}_{\mathrm{Albumin}}\right)$ excretion of $A s a h 1^{\mathrm{fl} / \mathrm{fl}} / \mathrm{Podo}^{\mathrm{Cre}}$ and Smpd1 ${ }^{-/-} /$Asah $^{\mathrm{fl} / \mathrm{fl}} / \mathrm{Podo} \mathrm{C}^{\text {Cre }}$ mice at 4 and 8 weeks. $n=3$ to $7(\mathbf{A}) ; n=6$ to 13 (B); $n=3$ to 4 (C). ${ }^{*} P<0.05$ versus WT/WT at 8 weeks; ${ }^{\dagger} P<0.05$ versus Asah $1^{\mathrm{fl} / \mathrm{fl}} / \mathrm{Podo}^{\text {Cre }}$ at 8 weeks; ${ }^{\ddagger} P<0.05$ versus $A s a h 1^{\mathrm{fl} / \mathrm{fl} /} / \mathrm{Podo}^{\text {Cre }}$ at 4 weeks. gbw, gram of body weight.

structural and functional integrity of renal glomeruli. In this study, our development of the Asaht $1^{\mathrm{f} / \mathrm{fl}} / \mathrm{Podo}{ }^{\mathrm{Cre}}$ mouse strain enabled this hypothesis to be further tested. Indeed, our data support that lysosomal Ac is a critical regulator of function and integrity of podocytes. Podocyte-specific deletion of the Ac $\alpha$ gene caused severe proteinuria and albuminuria. Surprisingly, no significant morphologic changes were detected in glomeruli of $A s a h 1^{\mathrm{f} / \mathrm{fl}} / \mathrm{Podo}^{\mathrm{Cre}}$ mice versus their control littermates on the basis of histologic analysis of periodic acid-Schiff stained kidney sections. However, we detected podocyte foot process effacement and microvillus formation in podocytes of Asaht ${ }^{\mathrm{t} / \mathrm{fl}} / \mathrm{Podo}^{\mathrm{Cre}}$ mice under TEM. Therefore, it can be concluded that podocyte-specific Asahl gene deletion may generate a novel mouse model for podocytopathy and nephrotic syndrome. To our knowledge, these results represent the first experimental evidence that podocytespecific dysfunctional mutation of Asahl gene induces podocytopathy and nephrotic syndrome. In previous studies, the earliest identifiable genetic defects leading to nephrotic syndrome were in genes encoding the slit diaphragm proteins, nephrin (NPHSl) and podocin (NPHS2). ${ }^{27,28}$ Nephrin plays critical roles in maintaining podocyte integrity, and loss-of-function mutations in NPHS1 result in congenital nephrotic syndrome and focal segmental glomerular sclerosis. ${ }^{27,29,30}$ NPHS2 mutations induce injury in part via effects on the NPHS1 and the actin cytoskeleton. Recessive NPHS2 mutations are the most common mutations identified in central European patients with early-onset steroidresistant nephrotic syndrome. ${ }^{28,31,32}$ Following the discovery of the role of NPHS1 and NPHS2, mutations in actin cytoskeleton-associated genes were identified in patients with nephrotic syndrome. ${ }^{33-35}$ More recent studies have revealed the contribution of mutations in genes encoding nuclear proteins, mitochondrial proteins, and glomerular basement membrane proteins. ${ }^{36}$ Mutations of SCARB2, the gene that encodes lysosomal integral membrane protein lysosomal integral membrane protein II (LIMP-II), a $\beta$ glucocerebrosidase receptor, have been reported to cause glomerular sclerosis. ${ }^{37}$ Because autophagy is an essential mechanism for maintenance of podocyte homeostasis, ${ }^{38-40}$ the dysregulation of autophagy can be considered as a potential mechanism for SCARB2-mediated podocyte injury. More recently, cathepsin D as a lysosomal aspartic proteinase has been found to be essential for the maintenance of podocyte function. Loss of cathepsin D in podocytes causes autophagy impairment, triggering the accumulation of toxic subunit c-positive lipofuscins as well as slit diaphragm proteins, followed by apoptotic cell death. ${ }^{24}$ Our results together with these previous findings indicate that lysosome dysfunction may be a potential mechanism mediating podocyte injury in $A s a h 1^{\mathrm{f} / / \mathrm{f}} / \mathrm{Podo}^{\mathrm{Cre}}$ mice.

Next, the steroid sensitivity of the development of podocytopathy and nephrotic syndrome was studied in Asahl $1^{\mathrm{f} / \mathrm{f}} / \mathrm{Podo}^{\mathrm{Cre}}$ mice, the rationale being that undetectable glomerular morphologic changes under light microscope and foot process effacement and microvillus formation in podocytes under TEM are hallmarks of steroid-sensitive nephrotic syndrome mice. ${ }^{41,42}$ However, dexamethasone phosphate, the corticosteroid typically used for treatment of steroid-sensitive nephrotic syndrome, was found to have no effect on the development of the nephrotic syndrome markers in Asahl $1^{\mathrm{f} / \mathrm{fl}} / \mathrm{Podo}^{\mathrm{Cre}}$ mice. Although previous studies have reported that glomerular expression levels of both $\alpha$-dystroglycan and $\beta$-dystroglycan are down-regulated during steroid-sensitive nephrotic syndrome, ${ }^{43}$ the reduction of glomerular $\alpha$-dystroglycan was not observed in Asahl $1^{\mathrm{f} / \mathrm{fl}} / \mathrm{Podo}^{\mathrm{Cre}}$ mice. These findings indicate that the nephrotic syndrome that developed in $A s a h 1^{\mathrm{fl} / \mathrm{fl}} / \mathrm{Podo}^{\mathrm{Cre}}$ mice is of a steroid- 
A Foot Process Effacement

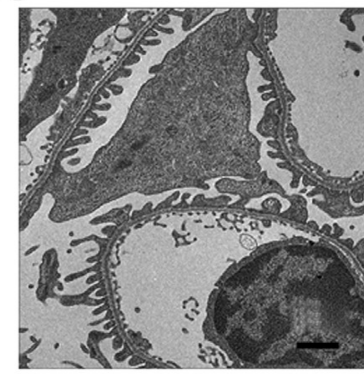

WTNT

B

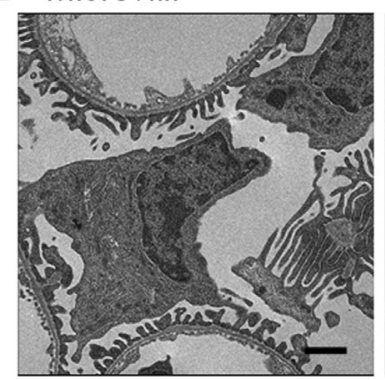

WTNT

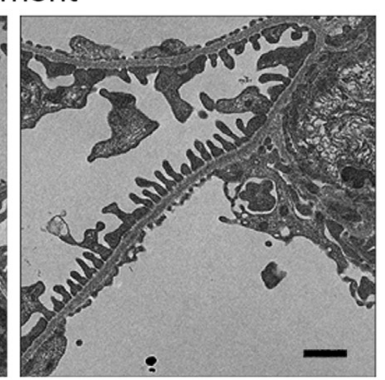

Smpd1 $1^{-1-}$

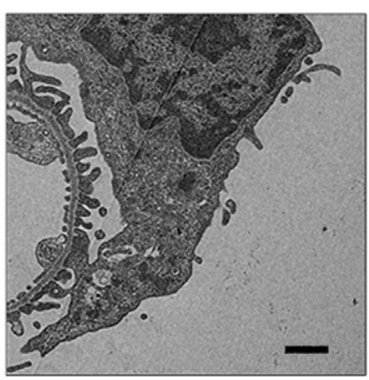

Smpd $1^{-1-}$

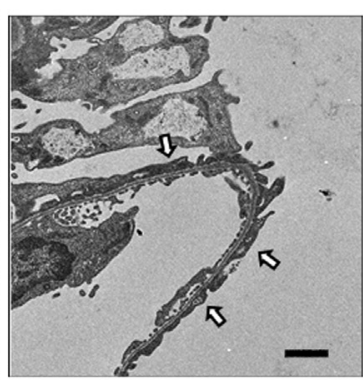

Asah $1^{\mathrm{fl} / \mathrm{fl} / \mathrm{Podo} \text { Cre }}$

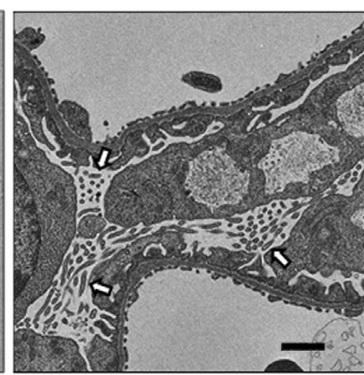

Asah $1^{\text {fl/ffl/Podo }}$ Cre

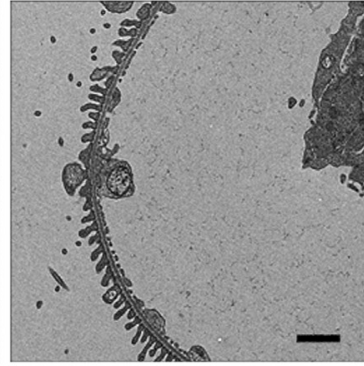

Smpd $1^{-1-1}$

Asah $1^{\mathrm{fl} / \mathrm{f} / \mathrm{P} / \mathrm{Podo} \text { Cre }}$

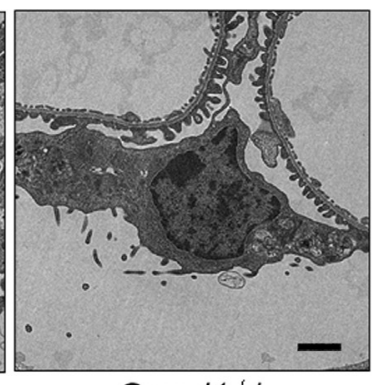

Smpd1 $1^{-1-1}$

Asah $1^{\text {fl/fil/Podo }}$ Cre

Figure 9 Inhibition of podocyte injury by global acid sphingomyelinase knockout. A: Representative images showing foot processes of podocytes in different groups of mice at 8 weeks. The foot process effacement (arrows) was observed in podocytes of Asah $1^{\mathrm{fl} / \mathrm{fl} / \text { Podo }}{ }^{\text {Cre }}$ mice at 8 weeks. B: Representative images showing microvilli of podocytes in different groups of mice at 8 weeks. The microvilli (arrows) were observed in podocytes of $A s a h 1^{\mathrm{fl} / \mathrm{fl}} / \mathrm{Podo}^{\mathrm{Cre}}$ mice at 8 weeks. $n=4$ (A and $\mathbf{B})$. Scale bars $=1 \mu \mathrm{m}(\mathbf{A}$ and $\mathbf{B})$.

resistant type. In this regard, mutations in or deletion of the S1P lyase gene in humans and mice has been reported to increase S1P and ceramide levels in blood or tissues, which results in steroid-resistant nephrotic syndrome with mesangial hypercellularity, glomerular hypertrophy, and glomerular fibrosis. ${ }^{6-9}$ In addition, both S1P and ceramide were elevated in kidneys of rats treated with an S1P lyase inhibitor, compared with a vehicle-treated control group. ${ }^{9}$ This led us to hypothesize that the nephrotic syndrome in the mice with a podocyte-specific Asahl gene knockout is caused by the accumulation of ceramide in glomeruli. Using LC-MS/MS, remarkable ceramide accumulation was detected in glomeruli isolated from $A s a h 1^{\mathrm{fl} / \mathrm{fl}} / \mathrm{Podo}^{\mathrm{Cre}}$ mice. Given the known contribution of ceramide to the development of insulin resistance and type 2 diabetes, we also addressed the question whether the glomerular ceramide accumulation observed in the podocyte-specific Asahl gene-deleted mice induced insulin resistance in podocytes. It was found that neither the blood glucose level nor glucose tolerance was significantly changed in the podocyte-specific Ac knockout mice compared with littermates with control genotypes. In addition, the albuminuric response of $A s a h l^{\mathrm{f} / \mathrm{fl}} / \mathrm{Podo}^{\mathrm{Cre}}$ mice was not altered by metformin hydrochloride, which is used for treatment of type 2 diabetes. In this regard, previous studies have demonstrated the existence of an inverse relationship between the level of ceramide in skeletal muscles and insulin sensitivity. ${ }^{44-46}$ It was found that inhibition of the $d e$ novo synthesis pathway prevents accumulation of ceramide and reduction of insulin sensitivity in mice fed a high-fat diet and in $\mathrm{db} / \mathrm{db}$ mice. ${ }^{47,48}$ Overexpression of Ac blocks saturated fatty acid-induced elevation in the level of ceramide in $\mathrm{C} 2 \mathrm{C} 12$ myotubes with concomitant prevention in reduction of insulin sensitivity. ${ }^{49}$ More recently, ceramide reduction due to activation of lysosomal Ac has been found to ameliorate diabetic nephropathy. ${ }^{4}$ Despite these observations of lysosomal Ac-dependent ceramide metabolism in insulin signaling, it remained unknown whether insulin sensitivity controlled by Ac-ceramide signaling plays an important role in the regulation of podocyte function. According to our results, insulin resistance may not be the key inducer of the podocytopathy and nephrotic syndrome induced by podocyte-specific Asahl gene deletion. Also, it is possible that insulin resistance induced by ceramide accumulation may not be reversed by metformin.

To confirm the role of glomerular ceramide accumulation in the observed pathology, Asah $1^{\mathrm{f} / \mathrm{f} /} / \mathrm{Podo}^{\mathrm{Cre}}$ mice carrying an additional knockout in the acid sphingomyelinase gene were generated $\left(\right.$ Smpd $^{-1-} /$ Asah $^{\mathrm{f} / \mathrm{fl}} / \mathrm{Podo}^{\mathrm{Cre}}$ mice). As expected, these mice exhibited significant reductions in glomerular ceramide accumulation compared with mice 
with the podocyte-specific Asahl gene deletion alone. Functionally, the proteinuria and albuminuria observed in the Asah ${ }^{\mathrm{f} / \mathrm{fl} /} / \mathrm{Podo}^{\mathrm{Cre}}$ mice was completely prevented in the double acid sphingomyelinase/podocyte-specific Ac gene knockouts. Morphologically, foot process effacement and microvillus formation were not observed in podocytes of $\operatorname{Smpd1}^{-1-} /$ Asahl $^{\mathrm{fl} / \mathrm{fl}} / \mathrm{Podo}^{\mathrm{Cre}}$ mice. These results suggest that normal ceramide metabolism exerts an important regulatory role on maintenance of podocyte integrity and that imbalanced ceramide metabolism may induce podocytopathy. To our knowledge, these results provide the first evidence that glomerular ceramide accumulation due to specific Ac dysfunction in podocytes serves as a critical mechanism activating or enhancing podocyte injury and nephrotic syndrome. In this regard, some previous studies in our laboratory have demonstrated that hyperhomocysteinemia induces ASM overexpression, leading to renal ceramide accumulation, podocyte injury, and glomerular sclerosis. $^{50,51}$ Activation of ASM by obesity contributes to nucleotide-binding oligomerization domain-like receptor containing pyrin domain 3 (NLRP3) inflammasome activation in podocytes and proteinuria. ${ }^{52}$ On the contrary, Smpdl gene deficiency ameliorates podocyte injury and glomerular sclerosis during hyperhomocysteinemia and obesity. ${ }^{50-52}$ More recently, it has been reported that Dribose induces ceramide accumulation and elevates exosome release, which are attenuated by inhibition of ASM activity in podocytes. ${ }^{23}$ In patients with diabetic kidney disease, glomerular acid sphingomyelinase-like phosphodiesterase $3 \mathrm{~b}$ mRNA expression is significantly increased compared with normal controls. In addition, knockout of sphingomyelinase-like phosphodiesterase $3 \mathrm{~b}$ protects podocytes from apoptosis induced by soluble urokinase plasminogen activator receptor. ${ }^{53}$ In patients with recurrent focal segmental glomerular sclerosis, however, the expression of sphingomyelinase-like phosphodiesterase $3 \mathrm{~b}$ has been found to be down-regulated in podocytes. Overexpression of sphingomyelinase-like phosphodiesterase $3 \mathrm{~b}$ or treatment with rituximab was able to prevent disruption of the actin cytoskeleton and podocyte apoptosis induced by patient sera. ${ }^{54}$ These results suggest that both accumulation and reduction in ceramide due to imbalance of associated enzyme activity may result in podocyte injury and renal diseases through different mechanisms. Our findings, together with these previous studies, provide strong evidence that abnormal ceramide metabolism due to imbalance of associated enzymes may play a crucial role in the development of podocyte injury and nephrotic syndrome.

In summary, the present results demonstrate that lysosomal Ac is essential for the maintenance of podocyte function and structural integrity. Podocyte-specific Asahl gene deletion leads to podocytopathy and nephrotic syndrome. Glomerular ceramide accumulation contributes to the molecular mechanism of podocyte injury in Asahl $1^{\mathrm{f} / \mathrm{fl}} / \mathrm{Podo}^{\mathrm{Cre}}$ mice. These findings shed new light on potential pathogenesis underlying podocytopathy and nephrotic syndrome and point to lysosomal acid ceramidase as a potential therapeutic target for prevention or treatment of nephrotic syndrome and other glomerular diseases.

\section{References}

1. Mundel P, Shankland SJ: Podocyte biology and response to injury. J Am Soc Nephrol 2002, 13:3005-3015

2. Pavenstadt H, Kriz W, Kretzler M: Cell biology of the glomerular podocyte. Physiol Rev 2003, 83:253-307

3. Bierzynska A, Soderquest K, Koziell A: Genes and podocytes: new insights into mechanisms of podocytopathy. Front Endocrinol (Lausanne) 2014, 5:226

4. Choi SR, Lim JH, Kim MY, Kim EN, Kim Y, Choi BS, Kim YS, Kim HW, Lim KM, Kim MJ, Park CW: Adiponectin receptor agonist AdipoRon decreased ceramide, and lipotoxicity, and ameliorated diabetic nephropathy. Metabolism 2018, 85:348-360

5. Park JH, Schuchman EH: Acid ceramidase and human disease Biochim Biophys Acta 2006, 1758:2133-2138

6. Janecke AR, Xu R, Steichen-Gersdorf E, Waldegger S, Entenmann A, Giner T, Krainer I, Huber LA, Hess MW, Frishberg Y, Barash H, Tzur S, Schreyer-Shafir N, Sukenik-Halevy R, Zehavi T, Raas-Rothschild A, Mao C, Muller T: Deficiency of the sphingosine1-phosphate lyase SGPL1 is associated with congenital nephrotic syndrome and congenital adrenal calcifications. Hum Mutat 2017, 38: 365-372

7. Lovric S, Goncalves S, Gee HY, Oskouian B, Srinivas H, Choi WI, et al: Mutations in sphingosine-1-phosphate lyase cause nephrosis with ichthyosis and adrenal insufficiency. J Clin Invest 2017, 127: 912-928

8. Prasad R, Hadjidemetriou I, Maharaj A, Meimaridou E, Buonocore F, Saleem M, Hurcombe J, Bierzynska A, Barbagelata E, Bergada I, Cassinelli H, Das U, Krone R, Hacihamdioglu B, Sari E, Yesilkaya E, Storr HL, Clemente M, Fernandez-Cancio M, Camats N, Ram N, Achermann JC, Van Veldhoven PP, Guasti L, Braslavsky D, Guran T, Metherell LA: Sphingosine-1-phosphate lyase mutations cause primary adrenal insufficiency and steroid-resistant nephrotic syndrome. J Clin Invest 2017, 127:942-953

9. Schumann J, Grevot A, Ledieu D, Wolf A, Schubart A, Piaia A, Sutter E, Cote S, Beerli C, Pognan F, Billich A, Moulin P, Walker UJ: Reduced activity of sphingosine-1-phosphate lyase induces podocyterelated glomerular proteinuria, skin irritation, and platelet activation. Toxicol Pathol 2015, 43:694-703

10. Yang S, Healey MC: The immunosuppressive effects of dexamethasone administered in drinking water to $\mathrm{C} 57 \mathrm{BL} / 6 \mathrm{~N}$ mice infected with Cryptosporidium parvum. J Parasitol 1993, 79:626-630

11. Mao-Ying QL, Kavelaars A, Krukowski K, Huo XJ, Zhou W, Price TJ, Cleeland C, Heijnen CJ: The anti-diabetic drug metformin protects against chemotherapy-induced peripheral neuropathy in a mouse model. PLoS One 2014, 9:e100701

12. Savin VJ, Sharma R, Lovell HB, Welling DJ: Measurement of albumin reflection coefficient with isolated rat glomeruli. J Am Soc Nephrol 1992, 3:1260-1269

13. Savin VJ, Terreros DA: Filtration in single isolated mammalian glomeruli. Kidney Int 1981, 20:188-197

14. Abais JM, Xia M, Li G, Gehr TW, Boini KM, Li PL: Contribution of endogenously produced reactive oxygen species to the activation of podocyte NLRP3 inflammasomes in hyperhomocysteinemia. Free Radic Biol Med 2014, 67:211-220

15. Raij L, Azar S, Keane W: Mesangial immune injury, hypertension, and progressive glomerular damage in Dahl rats. Kidney Int 1984, 26 : 137-143

16. Boini KM, Xia M, Abais JM, Li G, Pitzer AL, Gehr TW, Zhang Y, Li PL: Activation of inflammasomes in podocyte injury of mice on 
the high fat diet: effects of ASC gene deletion and silencing. Biochim Biophys Acta 2014, 1843:836-845

17. Li G, Xia M, Abais JM, Boini K, Li PL, Ritter JK: Protective action of anandamide and its COX-2 metabolite against 1-homocysteineinduced NLRP3 inflammasome activation and injury in podocytes. $\mathrm{J}$ Pharmacol Exp Ther 2016, 358:61-70

18. Li G, Chen Z, Bhat OM, Zhang Q, Abais-Battad JM, Conley SM, Ritter JK, Li PL: NLRP3 inflammasome as a novel target for docosahexaenoic acid metabolites to abrogate glomerular injury. J Lipid Res 2017, 58:1080-1090

19. Reed MJ, Meszaros K, Entes LJ, Claypool MD, Pinkett JG, Gadbois TM, Reaven GM: A new rat model of type 2 diabetes: the fat-fed, streptozotocin-treated rat. Metabolism 2000, 49: 1390-1394

20. Fan F, Chen CC, Zhang J, Schreck CM, Roman EA, Williams JM, Hirata T, Sharma M, Beard DA, Savin VJ, Roman RJ: Fluorescence dilution technique for measurement of albumin reflection coefficient in isolated glomeruli. Am J Physiol Renal Physiol 2015, 309: F1049-F1059

21. Regele HM, Fillipovic E, Langer B, Poczewki H, Kraxberger I, Bittner RE, Kerjaschki D: Glomerular expression of dystroglycans is reduced in minimal change nephrosis but not in focal segmental glomerulosclerosis. J Am Soc Nephrol 2000, 11:403-412

22. Xiong J, Xia M, Xu M, Zhang Y, Abais JM, Li G, Riebling CR, Ritter JK, Boini KM, Li PL: Autophagy maturation associated with CD38-mediated regulation of lysosome function in mouse glomerular podocytes. J Cell Mol Med 2013, 17:1598-1607

23. Hong J, Bhat OM, Li G, Dempsey SK, Zhang Q, Ritter JK, Li W, Li PL: Lysosomal regulation of extracellular vesicle excretion during d-ribose-induced NLRP3 inflammasome activation in podocytes. Biochim Biophys Acta Mol Cell Res 2019, 1866:849-860

24. Yamamoto-Nonaka K, Koike M, Asanuma K, Takagi M, Oliva Trejo JA, Seki T, Hidaka T, Ichimura K, Sakai T, Tada N, Ueno T, Uchiyama Y, Tomino Y: Cathepsin D in podocytes is important in the pathogenesis of proteinuria and CKD. J Am Soc Nephrol 2016, 27: $2685-2700$

25. Alghamdi TA, Majumder S, Thieme K, Batchu SN, White KE, Liu Y, Brijmohan AS, Bowskill BB, Advani SL, Woo M, Advani A: Janus kinase 2 regulates transcription factor EB expression and autophagy completion in glomerular podocytes. J Am Soc Nephrol 2017, 28: $2641-2653$

26. Li G, Huang D, Hong J, Bhat OM, Yuan X, Li PL: Control of lysosomal TRPML1 channel activity and exosome release by acid ceramidase in mouse podocytes. Am J Physiol Cell Physiol 2019, 317:C481-C491

27. Kestila M, Lenkkeri U, Mannikko M, Lamerdin J, McCready P, Putaala H, Ruotsalainen V, Morita T, Nissinen M, Herva R, Kashtan CE, Peltonen L, Holmberg C, Olsen A, Tryggvason K: Positionally cloned gene for a novel glomerular protein-nephrin-is mutated in congenital nephrotic syndrome. Mol Cell 1998, 1: $575-582$

28. Boute N, Gribouval O, Roselli S, Benessy F, Lee H, Fuchshuber A, Dahan K, Gubler MC, Niaudet P, Antignac C: NPHS2, encoding the glomerular protein podocin, is mutated in autosomal recessive steroid-resistant nephrotic syndrome. Nat Genet 2000, 24:349-354

29. Beltcheva O, Martin P, Lenkkeri U, Tryggvason K: Mutation spectrum in the nephrin gene (NPHS1) in congenital nephrotic syndrome. Hum Mutat 2001, 17:368-373

30. Santin S, Garcia-Maset R, Ruiz P, Gimenez I, Zamora I, Pena A, Madrid A, Camacho JA, Fraga G, Sanchez-Moreno A, Cobo MA, Bernis C, Ortiz A, de Pablos AL, Pintos G, Justa ML, HidalgoBarquero E, Fernandez-Llama P, Ballarin J, Ars E, Torra R, Group FSS: Nephrin mutations cause childhood- and adult-onset focal segmental glomerulosclerosis. Kidney Int 2009, 76: $1268-1276$

31. Karle SM, Uetz B, Ronner V, Glaeser L, Hildebrandt F, Fuchshuber A: Novel mutations in NPHS2 detected in both familial and sporadic steroid-resistant nephrotic syndrome. J Am Soc Nephrol 2002, 13:388-393

32. Hinkes BG, Mucha B, Vlangos CN, Gbadegesin R, Liu J, Hasselbacher K, Hangan D, Ozaltin F, Zenker M, Hildebrandt F; Arbeitsgemeinschaft fur Paediatrische Nephrologie Study Group: Nephrotic syndrome in the first year of life: two thirds of cases are caused by mutations in 4 genes (NPHS1, NPHS2, WT1, and LAMB2). Pediatrics 2007, 119:e907-e919

33. Kaplan JM, Kim SH, North KN, Rennke H, Correia LA, Tong HQ, Mathis BJ, Rodriguez-Perez JC, Allen PG, Beggs AH, Pollak MR: Mutations in ACTN4, encoding alpha-actinin-4, cause familial focal segmental glomerulosclerosis. Nat Genet 2000, 24:251-256

34. Brown EJ, Schlondorff JS, Becker DJ, Tsukaguchi H, Tonna SJ, Uscinski AL, Higgs HN, Henderson JM, Pollak MR: Mutations in the formin gene INF2 cause focal segmental glomerulosclerosis. Nat Genet 2010, 42:72-76

35. Gigante M, Pontrelli P, Montemurno E, Roca L, Aucella F, Penza R, Caridi G, Ranieri E, Ghiggeri GM, Gesualdo L: CD2AP mutations are associated with sporadic nephrotic syndrome and focal segmental glomerulosclerosis (FSGS). Nephrol Dial Transplant 2009, 24: $1858-1864$

36. Akchurin O, Reidy KJ: Genetic causes of proteinuria and nephrotic syndrome: impact on podocyte pathobiology. Pediatr Nephrol 2015, 30:221-233

37. Berkovic SF, Dibbens LM, Oshlack A, Silver JD, Katerelos M, Vears DF, Lullmann-Rauch R, Blanz J, Zhang KW, Stankovich J, Kalnins RM, Dowling JP, Andermann E, Andermann F, Faldini E, D'Hooge R, Vadlamudi L, Macdonell RA, Hodgson BL, Bayly MA, Savige J, Mulley JC, Smyth GK, Power DA, Saftig P, Bahlo M: Array-based gene discovery with three unrelated subjects shows SCARB2/LIMP-2 deficiency causes myoclonus epilepsy and glomerulosclerosis. Am J Hum Genet 2008, 82:673-684

38. Li G, Li CX, Xia M, Ritter JK, Gehr TW, Boini K, Li PL: Enhanced epithelial-to-mesenchymal transition associated with lysosome dysfunction in podocytes: role of p62/Sequestosome 1 as a signaling hub. Cell Physiol Biochem 2015, 35:1773-1786

39. Hartleben B, Godel M, Meyer-Schwesinger C, Liu S, Ulrich T, Kobler S, Wiech T, Grahammer F, Arnold SJ, Lindenmeyer MT, Cohen CD, Pavenstadt H, Kerjaschki D, Mizushima N, Shaw AS, Walz G, Huber TB: Autophagy influences glomerular disease susceptibility and maintains podocyte homeostasis in aging mice. J Clin Invest 2010, 120:1084-1096

40. Cina DP, Onay T, Paltoo A, Li C, Maezawa Y, De Arteaga J, Jurisicova A, Quaggin SE: MTOR regulates autophagic flux in the glomerulus. Autophagy 2012, 8:696-698

41. Fogo AB, Lusco MA, Najafian B, Alpers CE: AJKD atlas of renal pathology: minimal change disease. Am J Kidney Dis 2015, 66: 376-377

42. Mendez GP, Enos D, Moreira JL, Alvaredo F, Oddo D: Nephrotic syndrome due to minimal change disease secondary to spider bite: clinico-pathological case of a non-described complication of latrodectism. Clin Kidney J 2017, 10:229-232

43. Barisoni L, Mundel P: Podocyte biology and the emerging understanding of podocyte diseases. Am J Nephrol 2003, 23: $353-360$

44. Dobrzyn A, Gorski J: Ceramides and sphingomyelins in skeletal muscles of the rat: content and composition: effect of prolonged exercise. Am J Physiol Endocrinol Metab 2002, 282: E277-E285

45. Straczkowski M, Kowalska I, Nikolajuk A, Dzienis-Straczkowska S, Kinalska I, Baranowski M, Zendzian-Piotrowska M, Brzezinska Z, Gorski J: Relationship between insulin sensitivity and sphingomyelin signaling pathway in human skeletal muscle. Diabetes 2004, 53: 1215-1221

46. Summers SA: Ceramides in insulin resistance and lipotoxicity. Prog Lipid Res 2006, 45:42-72 
47. Schmitz-Peiffer C: Targeting ceramide synthesis to reverse insulin resistance. Diabetes 2010, 59:2351-2353

48. Ussher JR, Koves TR, Cadete VJ, Zhang L, Jaswal JS, Swyrd SJ, Lopaschuk DG, Proctor SD, Keung W, Muoio DM, Lopaschuk GD: Inhibition of de novo ceramide synthesis reverses diet-induced insulin resistance and enhances whole-body oxygen consumption. Diabetes 2010, 59:2453-2464

49. Chavez JA, Holland WL, Bar J, Sandhoff K, Summers SA: Acid ceramidase overexpression prevents the inhibitory effects of saturated fatty acids on insulin signaling. J Biol Chem 2005, 280: 20148-20153

50. Boini KM, Xia M, Li C, Zhang C, Payne LP, Abais JM, Poklis JL, Hylemon PB, Li PL: Acid sphingomyelinase gene deficiency ameliorates the hyperhomocysteinemia-induced glomerular injury in mice. Am J Pathol 2011, 179:2210-2219

51. Boini KM, Xia M, Abais JM, Xu M, Li CX, Li PL: Acid sphingomyelinase gene knockout ameliorates hyperhomocysteinemic glomerular injury in mice lacking cystathionine-beta-synthase. PLoS One 2012, 7:e45020

52. Boini KM, Xia M, Koka S, Gehr TW, Li PL: Instigation of NLRP3 inflammasome activation and glomerular injury in mice on the high fat diet: role of acid sphingomyelinase gene. Oncotarget 2016, 7:19031-19044

53. Yoo TH, Pedigo CE, Guzman J, Correa-Medina M, Wei C, Villarreal R, Mitrofanova A, Leclercq F, Faul C, Li J, Kretzler M, Nelson RG, Lehto M, Forsblom C, Groop PH, Reiser J, Burke GW, Fornoni A, Merscher S: Sphingomyelinase-like phosphodiesterase 3b expression levels determine podocyte injury phenotypes in glomerular disease. J Am Soc Nephrol 2015, 26:133-147

54. Fornoni A, Sageshima J, Wei C, Merscher-Gomez S, AguillonPrada R, Jauregui AN, Li J, Mattiazzi A, Ciancio G, Chen L, Zilleruelo G, Abitbol C, Chandar J, Seeherunvong W, Ricordi C, Ikehata M, Rastaldi MP, Reiser J, Burke GW 3rd: Rituximab targets podocytes in recurrent focal segmental glomerulosclerosis. Sci Transl Med 2011, 3:85ra46 